\title{
TUJUAN PENGGUNAAN PROSES KEPERAWATAN
}

\author{
Atikah Ulfah Marwa/181101106 \\ ninanamanis@gmail.com
}

\begin{abstract}
Abstrak
Latar Belakang : Ilmu keperawatan adalah ilmu terapan sintesi dari ilmu-ilmu dasar dan ilmu keperawatan. Wawasan ilmu keperawatan mencakup ilmu yang mempelajari bentuk dan sebab tidak sepenuhnya kebutuhan dasar manusia serta upaya mencapai pemenuhan kebutuhan tersebut. Kebutuhan dasar manusia meliputi bio, psiko, sosio, kultural, dan spiritual, Proses keperawatan adalah metode dimana suatu konsep diterapkan dalam praktik keperawatan. Tujuan: untuk mengetahui tujuan penggunaan proses keperawatan baik pada mahasiswa. Metode Penelitian :literature review dengan cara menganalisis artikel, jurnal maupun text book. Artikel yang digunakan 14 referensi yang diterbitkan sepuluh tahun terakhir yang menggunakan google scholar, google book dan science direct. Hasil : Dari hasil pencarian literature didapatkan tujuan dalam penggunaan proses keperawatan adalah: indentifikasi masalah dan mencari sejumlah tindakan alternatif untuk memecahkan masalah Kesimpulan : Mahasiswa sebaiknya mempelajari lebih dalam konsep dasar keperawatan, tak hanya tujuan namun sejarah, manfaat dan lain-lainnya dipelajari kembali.
\end{abstract}

Kata kunci : proses keperawatan, asuhan keperawatan, metodologi keperawatan

\begin{abstract}
Background: Nursing is an applied science of synthesis from the basic sciences and nursing. Nursing insights encompass the science that shapes and causes not in accordance with human needs with efforts to achieve these fulfillment needs. Basic human needs include bio, psycho, social, cultural, and spiritual. Nursing process is a method in which a concept is applied in nursing practice. Objective: to find out the purpose of using a good nursing process in students. Research Methods: literature review by analyzing articles, journals and textbooks. The article used 14 references published over the last ten years using Google Scholar, Google Books and Science Direct. Results: From the literature search results obtained objectives in the use of the nursing process are: identification of problems and finding alternative solutions to solve problems Conclusion: Students get more help in the basic concepts of nursing, not just research objectives, benefits and others that are recovered.
\end{abstract}

Keywords: nursing process, nursing care, nursing care 


\section{PENDAHULUAN}

Ilmu keperawatan adalah ilmu terapan sintesis dari ilmu-ilmu dasar dan ilmu keperawatan. Wawasan ilmu keperawatan mencakup ilmu yang mempelajari bentuk dan sebab tidak sepenuhnya kebutuhan dasar manusia serta upaya mencapai pemenuhan kebutuhan tersebut. Kebutuhan dasar manusia meliputi bio, psiko, sosio, kultural, dan spiritual. (Suprajitno,2004)

Proses keperawatan adalah metode dimana suatu konsep diterapkan dalam praktik keperawatan (Muhith Abdul., 2015) . Standar praktik profeisonal proses keperawatan terdiri dari lima tahap yang sequensial dan berhubungan yaitu pengkajian, diagnosis, perencanaan, pelaksanaan, dan evaluasi (lyer et al., 1996). Metodologi prose keperawatan merupakan metodologi penyelesaian masalah kesehatan klien secara ilmiah berdasarkan pengetahuan ilmiah serta menggunakan teknologi kesehatan dan keperawatan, meliputi tahapan; pengkajian, merumuskan diagnosis keperawatan, perencanaan, implementasi, dan evaluasi.
Praktik keperawatan adalah tindakan mandiri perawatan profesional melalui kerja sama yang bersifat kolaboratif dengan klien dan tenaga kesehatan lain dalam memberikan asuhan keperawatan sesuai lingkup wewenang dan tanggung jawabnya (Suprijitno,2004). Asuhan keperawatan adalah suatu proses atau rangkaian kegiatan pada praktik keperawatan yang langsung diberikan kepada klien pada berbagai tatanan pelayanan kesehatan, dalam upaya pemenuhan kebutuhan dasar manusia, dengan menggunakan metodologi proses keperawatan, berpedoman pada standar praktik keperawatan, dilandasi etik dan etika keperawatan, dalam lingkup wewenang serta tanggung jawab keperawatan. (Suprijitno,2004)

Penelitian ini secara umum bertujuan untuk mengetahui tujuan penggunaan proses keperawatan baik pada mahasiswa, klien, dan tenaga kesehatan lainnya. Rumah sakit sebagai pemberi layanan kesehatan bertanggung jawab untuk memberikan pelayanan yang bermutu dan aman. Mahasiswa perlu mengetahui konsep dasar dalam

(Suprijitno,2004) 
melakukan proses keperawatan yang akan berguna saat di rumah sakit.

\section{METODE PENELITIAN}

Metoode penelitian yang digunakan adalah literature review dengan cara menganalisis artikel, jurnal maupun text book yang berkaitan dengan pembelajaran mahasiswa keperawatan dengan tujuan penggunaan proses keperawatan.

Artikel yang digunakan 14 referensi yang diterbitkan sepuluh tahun terakhir yang menggunakan google scholar, google book dan science direct. Dalam mencari artikel, kata kunci yang digunakan ialah konsep keperawatan, tujuan penggunaan proses keperawatan.

\section{HASIL}

Dari hasil pencarian literature didapatkan tujuan dalam penggunaan proses keperawatan adalah: Memiliki keterampilan dalam memecahkan masalah meliputi pengumpulan informasi, indentifikasi masalah dan mencari sejumlah tindakan alternatif untuk memecahkan masalah, dapat membantu klien dalam mencapai tingkat kesehatan dan kesejahteraan, dapat membantu klien beradaptasi maksimal terhadap gaya hidup, menganalisa data-data yang dapat mencapai kesimpulan yang logis dalam penyelesaian masalah secara rasional.

\section{PEMBAHASAN}

Metode asuhan yang dapat dipertanggung jawabkan secara ilmiah. Metode asuhan untuk praktik proofesional tersebut adalah proses keperawatan, suatu rangkaian asuhan yang terdiri dari pengkajian, menyusun diagnosis keperawatan, penrencanaan tindakan, implemenasi dan evaluasi. (Muhith, Abdul, 2015)

Proses keperawatan menjamin perawatan yang berkualitas. Adalah esensial untuk melaksanakan proses keperawatan dengan cara konsisten di seluruh program keperawatan dan pusat perawatan kesehatan. Konsisten dalam mengajar membantu mahasiswa dan perawat pelaksana dalam memindahkan pengetahannya dari kelas ke lingkungan praktik.

Proses keperawatan adalah a) didasarkan pada pendekatan penyelesaian masalah,b) ditentukan pada standar praktik American Nurses 
Association (1973), c) dasar untuk standar kinerja dan asuhan keperawatan, d) kerangka hukum untuk praktik keperawatan dan e) inti dari pemantauan jaminan kualitas (quality assurance). Proses keperawatan didasarkan pada pendekatan penyelesaian masalah.

Metodologi proses keperawatan merupakan metodologi penyelesaian masalah kesehatan klien secara ilmiah berdasarkan pengetahuan ilmiah serta menggunakan teknologi kesehatan dan keperawatan, meliputi tahapan;

1. pengkajian tahapan ini mencakup pengumpulan data,analisi/ interpretasi data tentang kondisi bio,psiko, sosio, kultural, dan spritua klien,

2. merumuskan diagnosis keperawatan, diagnosis keperawatan adalah pernyataan yang dirumuskan berdasarkan data yang terkumpul dan berpau rumusan tentang respons klien terhadap masalah kesehatan serta faktor penyebab (etiologi) yang berkontribusi terhadap timbulnya masalah yang perlu diatasi dengan tindakan/intervensi keperawatan,
3. perencanaan, perencanaan asuhan keperawata (nursing care plan) adalah acuan tertulis yang terdiri dari berbagai intervensi keperawatan yang diriencanakan dapat mengatasi diagnosis keperawatan sehingga klien dapat terpenuhi kebutuhan dasarnya. Sifat intervensi keperawatan yang dapat dilakukan perawat, yaitu bersifat bantuan, bersifat higenis, bersifat rehabilitas, bersifat suportif, bersifat preventif, bersifat observasi, dan memberikan informasi yang akurat dan memuaskan ruang pengobatan.

4. implementasi, merupakan bagian aktif dalam asuhan keperawatan, yaitu perawat melakukan tindakan sesuai rencana. Tindakan ini bersifat intelektual, teknis, dan interpersonal berupa berbagai upaya memenuhi kebutuhan dasar klien. Tindakan keperawatan meliputi

tindakan keperawatan

observasi keperawatan

pendidikan

kesehatan/keperawan, dan 
tindakan medis yang dilakukan perawat (tugas limpah)

5. evaluasi, merupakan tahap akhir dari rangkaian proses keperawatan yang berguna apakah tujuan dari tindakan keperawtan yang telah dilakukan tercapai atau perlu pendekatan lain. (Suprijitno,2004)

dari penjabaran diatas dapat diketahui tujuan dari penggunaan prose kesehatan adalah Memiliki keterampilan dalam memecahkan masalah meliputi pengumpulan informasi, indentifikasi masalah dan mencari sejumlah tindakan alternatif untuk memecahkan masalah, dapat membantu klien dalam mencapai tingkat kesehatan dan kesejahteraan, dapat membantu klien beradaptasi maksimal terhadap gaya hidup, menganalisa data-data yang dapat mencapai kesimpulan yang logis dalam penyelesaian masalah secara rasional.

Diagnosa keperawatan adalah keputusan tentang respon keluarga tentang masalah kesehatan actual atau potensial, sebagai dasar seleksi intervensi keperawatan untuk mencapai tujuan asuhan keperawatan sesuai dengan kewenangan perawatan.
Tahapan dalam diagnosa keperawatan keluarga sesuai dengan kewenangan perawatan antara lain: analisa data, perumusan masalah, dan prioritas masalah (Harnilawati, 2013)

\section{KESIMPULAN DAN SARAN}

\section{KESIMPULAN}

Kesimpulan dari hasil penelitian literature view tujuan penggunaan proses keperawatan adalah tentang metodologi proses keperawatan yang memiliki tahapan yakni pengkajian, merumuskan diagnosis keperawatan, perencanaan, implementasi, evaluasi, dan tujuan dari penggunaan proses keperawatan ialah memiliki keterampilan dalam memecahkan masalah di rumah sakit, membantu klien beradaptasi maksimal terhadap gaya hidup, menganalisa data-data yang dapat mencapais kesimpulan yang logis dalam penyelesaian masalah yang rasional.

\section{SARAN}

Mahasiswa sebaiknya mempelajari lebih dalam konsep dasar keperawatan, tak hanya tujuan namun sejarah, 
manfaat dan lain-lainnya dapat dipelajari kembali

\section{REFERENSI}

Aba, D. M., Hartono, B., \& Sari, S. M. (2018). ANALISIS PERILAKU ORGANISASI DALAM PENDOKUMENTASIAN ASUHAN KEPERAWATAN DI RUANG RAWAT INAP CENDRAWASIH RUMAH SAKIT UMUM DAERAH (RSUD) ARI. Menara Ilmu, 12(11).

Allen, Carol Vestal. (1998). Memahami Proses Keperawatan dengan Latihan. Jakarta : EGC

Dewi, S. R., \& Ners, S. K. (2015). Buku ajar keperawatan gerontik. Deepublish.

Diantika, P., Azizah, L. M. R., \& Achwandi, M. (2019). ASUHAN KEPERAWATAN HAMBATAN MOBILITAS FISIK PADA PASIEN CVA INFARK DI RSI SAKINAH MOJOKERTO.

Harnilawati. (2013). konsep dan proses keperawatan keluarga. Takalar: Pustaka As Salam

Muhith, A. (2015). Pendidikan keperawatan jiwa: Teori dan aplikasi. Penerbit Andi.

Simamora, R. H. (2019). Menjadi Perawat yang: CIH'HUY. Surakarta: Kekata Publisher.

Suprijitno. (2004). Asuhan Keperawatan Keluarga : Aplikasi dalam Praktik. Jakarta: EGC
Syukur, A. (2018). HUBUNGAN

BEBAN KERJA DENGAN

DOKUMENTASI ASUHAN

KEPERAWATAN. NERSPEDIA

JOURNAL, 1(2), 164-171. a

Tari, C. (2019). PENTINGNYA PENGAPLIKASIAN BERPIKIR KRITIS BAGI PERAWAT DI IGD.

Tutupoho, R. A. N., Azizah, L. M. R., \& Sudarsih, S. (2018). ASUHAN KEPERAWATAN PADA KLIEN YANG MENGALAMI HALUSINASI PENDENGARAN PADA KASUS SKIZOFRENIA PARANOID DI WILAYAH KERJA PUSKESMAS WATES KOTA MOJOKERTO.

Wahyudi, A. S., \& Wahid, A. (2016). Ilmu Keperawatan Dasar. Jakarta: Mitra Wacana Media.

Wijayanti, S. L., Azizah, L. M. R., \& Peni, T. (2019). Asuhan Keperawatan Kerusakan Integritas kulit Pada Pasien Diabetes Mellitus Dengan Luka Ganggren di Ruang Walisongo RSI Sakinah Mojokerto.

Wulandari, A., Azizah, L. M. R., \& Achwandi, M. (2019). Asuhan Keperawatan Nyeri Pada Lansia Di UPTD Pesanggrahan PMKS Mojopahit Kabupaten Mojokerto.

Yudiernawati, A., Setyosari, P., Degeng, I. N. S., \& Rudianto, A. (2015). Pengaruh Strategi Pembelajaran dan Gaya Kognitif terhadap Prestasi Belajar Aplikasi Proses Keperawatan pada Pembelajaran Klinik Keperawatan. Jurnal Pendidikan Humaniora (JPH), 3(1), 31-40. 
Yugistyowati, A., \& Santoso, S. (2018). Pengetahuan Perawat Tentang Family Centered-Care Dengan Sikap Dalam Pemberian Asuhan Keperawatan Di
Ruang Rawat Inap Anak. Jurnal Keperawatan Respati Yogyakarta, 5 , 39-44. 